\title{
СПЕЦИФИКА ФОРМИРОВАНИЯ И ТРАНСФОРМАЦИИ ОЦЕНКИ ОБЩЕСТВЕННОГО БЛАГОПОЛУЧИЯ В КОНТЕКСТЕ МЕЖДИСЦИПЛИНАРНЫХ ИССЛЕДОВАНИЙ ОБРАЗА КОММУНИЗМА
}

\author{
Петренко Максим Степанович1,2, \\ petmaxim@yandex.ru \\ Дукарт Сергей Александрович3,4,5, \\ dukart@mail.ru \\ 1 Новосибирский государственный университет экономики и управления, \\ Россия, 630099, г. Новосибирск, ул. Каменская, 52/1 \\ 2 Новосибирский юридический институт (филиал) \\ Национального исследовательского Томского государственного университета, \\ Россия, 630099, г. Новосибирск, ул. Советская, 7 \\ ${ }^{3}$ Национальный исследовательский Томский политехнический университет, \\ Россия, 634050, г. Томск, пр. Ленина, 30 \\ 4 Западно-Сибирский филиал Российского государственного университета правосудия, \\ Россия, 634050, г. Томск, пл. Ленина, 2 \\ 5 Томский государственный университет систем управления и радиоэлектроники, \\ Россия, 634050, г. Томск, пр. Ленина, 40
}

Петренко Максим Степанович, кандидат исторических наук, доцент кафедры мировой экономики, международных отношений и права Новосибирского государственного университета экономики и управления; доцент кафедры общественных наук Новосибирского юридического института (филиала) Национального исследовательского Томского государственного университета.

Дукарт Сергей Александрович, кандидат исторических наук, доцент отделения социальногуманитарных наук Школы базовой инженерной подготовки Национального исследовательского Томского политехнического университета; доцент кафедры гуманитарных и социальноэкономических дисциплин Западно-Сибирского филиала Российского государственного университета правосудия; доцент кафедры экономики Томского государственного университета систем управления и радиоэлектроники.

В статье анализируется трансформация образа благополучного будущего от советского поколения к поколению Z. Актуальность обусловлена необходимостью понимания специфики формирования оценки состояния благополучия и ее связи с мотивацией и активностью современного поколения. Цель - разработка и апробация методологического инструментария исследования проблемы благополучия. В исследовании используется методология междициплинарного синтеза. На основе теорий К. Альдерфера и К. Герцберга трактуется связь базовой мотивации общества с изменением базисных элементов образа будущего. Описание модели «трансформирующей призмы» позволяет определить причины противоречий в научных исследованиях при оценке картины благополучия. На основе исторического метода исследуются образ коммунизма и его значение в оценке благополучия людьми, принадлежащими к советскому поколению. При помощи социологического опроса выявляются ключевые компоненты образа будущего поколения Z. Сравнительный анализ позволяет оценить корректность применения модели «трансформирующей призмы» для понимания причин отдельных элементов желаемой модели благополучия. Результаты: использование методологии междисциплинарного синтеза позволяет существенно расширить горизонты научного познания. Применение модели «трансформирующей призмы» позволяет сделать более точные 
и корректные выводы относительно природы постоянных и переменных элементов в образе благополучия исследуемого поколения.

Ключевые слова: Благополучие, «трансформирующая призма», модель, мотивация, коммунизм, образ будущего.

\section{Введение}

Оценка благополучия общества традиционно используется как показатель эффективности государственного управления. Именно данная проблематика и всё, что с ней так или иначе связано, привлекает внимание исследователей на протяжении всей жизни человечества в целом. Тем не менее неоднозначность трактовки терминологии, субъективность понимания вектора и результатов достижения искомого результата не может поставить окончательную точку в изучении данной проблемы как в научной сфере, так и в сфере политической практики. Можно предположить, что негативная оценка государственного управления обществом, как правило, происходит на основе сравнения динамики собственного материального благосостояния в разные временные периоды жизненного цикла. При том зачастую мерилом здесь выступает не только объективные показатели дохода, количества материальных благ, но и субъективное ощущение удовлетворенности, удовольствия от жизни или счастья. Другими словами, общество может быть удовлетворено существующим уровнем благополучия и чувствовать себя счастливым в том числе, если результат превзошел ожидания или если образ благополучия в сознании соответствует реальности. В свою очередь, формирование этого образа является функцией от множества факторов, из которых только часть относится к собственному жизненному опыту. Но и даже эти, созданные или полученные в ходе жизненного опыта базисные установки, трансформируются или преломляются через то, что заложено внешним воздействием в процессе формирования личности человека через воспитание. Получается, что формируемый образ будущего, к которому стремится человек, является, в том числе, проекцией установок и жизненного опыта предыдущего поколения.

В свою очередь, социальная, политическая, экономическая активность человека, его работоспособность определяется его мотивацией и его удовлетворенностью при оценке результативности движения к некому намеченному им самим будущему.

Таким образом, если свести термин «благополучие» к состоянию удовлетворенности и неудовлетворенности общества имеющимся набором благ, представляется интересным применение традиционных психологических теории мотиваций для объяснения трансформации ключевых элементов парадигмы российского общества, поскольку именно в них достаточно наглядно описывается связь между такими компонентами, как мотивация-удовлетворенность-действия. В частности, в качестве методологической базы предполагается использование содержательных теорий мотиваций К. Альдерфера [1] и Ф. Герцберга [2].

Используя методы абстракции, аналогии, индукции на основе этих теорий гипотетически перенесем основные выводы с одного работника на общество в целом, предположив, что стремление к счастью, благополучию и росту благосостояния является основным мотиватором трудовой деятельности и общества, и каждого отдельного его члена. Продолжая эту аналогию, исходя из теории ERG Клейтона Альдерфера, можно предположить, что общество также может быть мотивировано либо на уровне Existence (существование), либо на Relatedness (потребности связи), либо на Growth (рост, развитие). Потребности существования для общества сродни ситуации борьбы за выживание, ключевыми критериями данного состояния являются наличие установок на безопас- 
ность, удовлетворение потребностей в материальных благах, прежде всего в товарах первой необходимости. Наличие преобладающих социальных потребностей или потребностей связи можно сравнить в стремлении к единству, коллективизму, объединению, стиранию социальных различий. Ну и, наконец, достижение обществом стадии Growth будет выражаться в появлении желания осмыслить путь человечества, обеспечить возможности для развития и благополучия каждого его члена. Предложенные Альдерфером группы потребностей расположены в иерархическом порядке. При этом движение от одной группы к другой может идти в разных направлениях, т. е. в нашем случае, если вдруг общество осознает невозможность движения вверх в сторону потребностей роста, оно вполне может опуститься вниз, подменив представление о благополучии как возможности саморазвития человека, например, достижением только определенного уровня материального благосостояния.

Вторым методологическим компонентом нашей гипотезы может выступить двухфакторная теория Ф. Герцберга, согласно которой необходимо выделять гигиенические факторы и мотиваторы, влияющие на отношение человека к труду. В классическом виде гигиенические факторы - это среда, в которой осуществляется работа, мотиваторы сама работа. Согласно Герцбергу, при отсутствии или недостаточной степени присутствия гигиенических факторов у человека возникает неудовлетворение работой. Однако если они достаточны, то сами по себе не вызывают удовлетворения работой и не могут мотивировать человека на что-либо. В отличие от этого отсутствие или неадекватность мотиваторов не приводит к неудовлетворенности работой. Но их наличие в полной мере вызывает удовлетворение и мотивирует работников на повышение эффективности деятельности [3].

По сути, с точки зрения Герцберга, именно эффективный менеджмент способствует созданию гигиенических факторов. Однако если внимательно присмотреться к содержанию гигиенических факторов, к которым относятся условия работы, политика администрации, заработная плата, социальный статус, межличностные отношения, то можно заметить, что их оценка со стороны работника является продуктом преломления реальной ситуации через его собственное сознание. Стоит предположить, что именно здесь кроется ответ на вопрос «Каким образом не самые лучшие со стороны внешнего наблюдателя условия трансформируются в состояние удовлетворенности ими?». Возможно, дело в «трансформирующей призме».

\section{Модель «трансформирующей призмы» и методологические принципы}

«Трансформирующую призму» можно представить как систему установок, базисных принципов в человеческом сознании, составляющих основу мировоззрения, сформированных на основании жизненного опыта, воспитания и идеологии, через которую, в свою очередь, происходит преломление информационных сигналов, поступающих из внешней среды (см. рис.). Сама призма, если использовать терминологию Имре Лакатоса [4], состоит из «твердого ядра» и «защитной оболочки». «Жесткое ядро» - это устойчивые стереотипы и установки, состоящие из общечеловеческих ценностей, норм морали, культурных ориентаций, присущих данному этносу. «Защитная оболочка» содержит суждения, осуществляющие вариативную связь между этим «жестким ядром» и окружающим миром, и ее задача, помимо прочего, не допускать разрушение «твердого ядра». Представляется, что Герцберг, вводя термин «гигиенические факторы», имел в виду именно действие «защитной оболочки». «Защитная оболочка» представляет собой переменные, формируемые в результате воздействия факторов внешней среды в ходе воспитательного процесса, собственного жизненного опыта и информационно- 
идеологического воздействия. Последнее следует выделить особо: очевидно, что соответствующая идеологическая обработка создает благодатную почву в появлении установок общественного сознания, достаточных для формирования гигиенических факторов удовлетворения. Напротив, изменение вектора пропагандистского воздействия автоматически приводит к разрушению оболочки «трансформирующей призмы» и вектор удовлетворенности общества меняется на противоположный. Но замена установок происходит не одномоментно, а предполагает временной лаг на постепенное вытеснение и замещение установок. Характерной особенностью «трансформирующей призмы» этого периода будет состояние дуализма, наличия когнитивного диссонанса в мировосприятии, когда в типичном человеческом сознании могут сосуществовать одновременно противоположные по смыслу образы и установки. В нашем случае «образ будущего» периода предыдущего поколения должен сохранять свою привлекательность, но переходить в разряд утопического, недостижимого, неактуального. Наличие дуальных установок в сознании может подтверждаться сочетанием резких негативных эмоциональных оценок объекта, с одной стороны, и признанием его объективных положительных качественных характеристик - с другой. Интересно, что при этом возможно даже осознание и признание человеком факта несовпадения мысленных конструкций и реальности, но используемые оценочные характеристики будут по-прежнему содержать нестыковки, подмены понятий и логические противоречия.

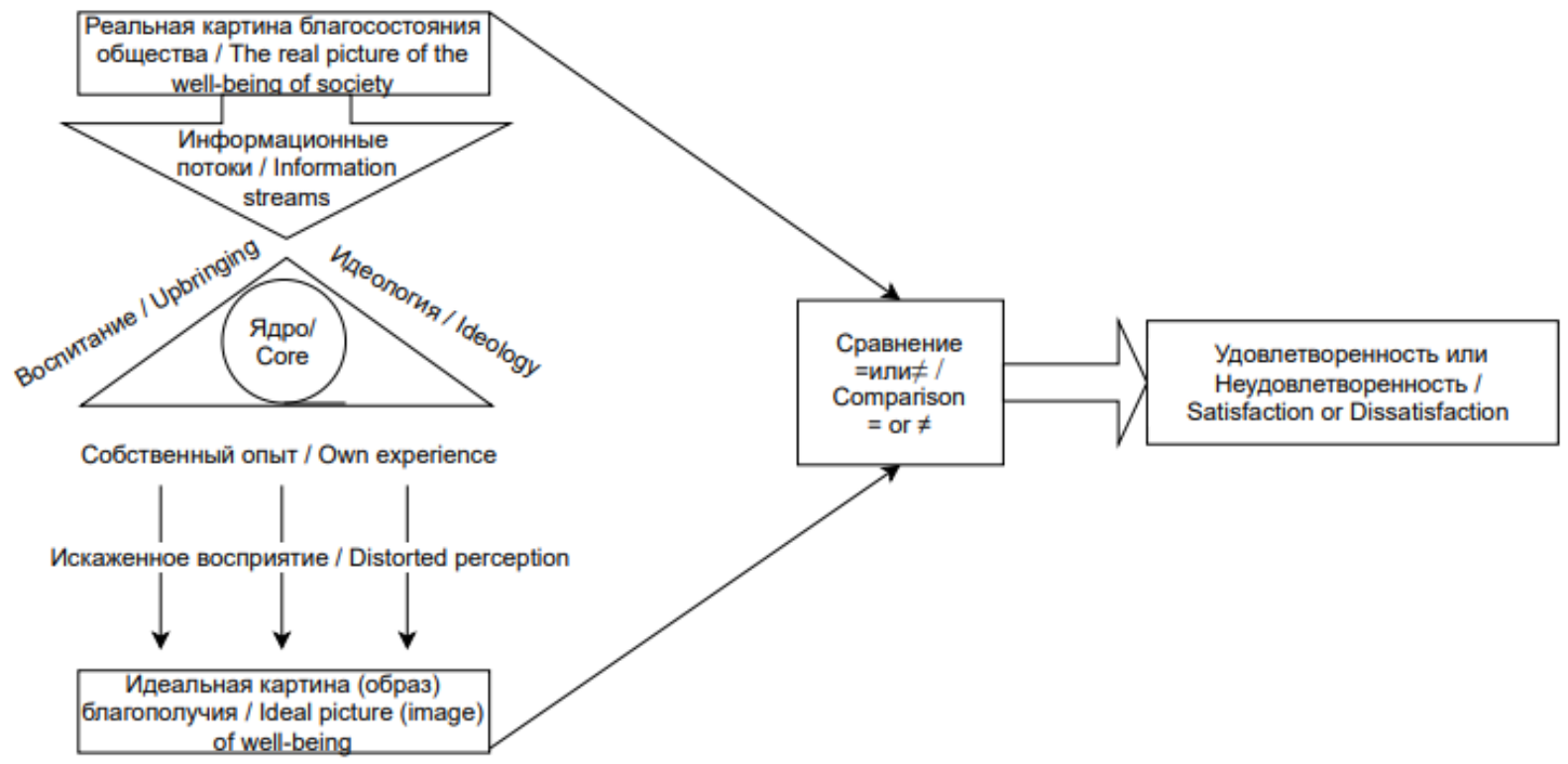

Рисунок. Искажение восприятия реальной действительности благодаря «трансформирующей призме»

Figure. Distortion of perception of reality due to the «transforming prism»

Таким образом, формирование идеального образа (картины) будущего происходит вследствие преломления воспринимаемых информационных сигналов от реальной жизни (объективно существующая картина благополучия) через «трансформирующую призму». Дальнейшее сравнение двух этих картин приводит к чувству удовлетворенности или неудовлетворенности у человека, которое, в свою очередь, формирует положительную или отрицательную оценку реальности и мотивирует или демотивирует человеческую деятельность. 
И наконец, еще один методологически важный момент. По мере взросления и старения человека «защитная оболочка» и «трансформирующая призма» будут также проходить свой жизненный цикл через стадии зарождения (формирования), взросления (закостенения, консервации) и разрушения (смерти), поэтому, очевидно, что научные исследования общественного благополучия должны понимать и выделять специфику изучаемого объекта. Для корректного исследования процессов трансформации мировоззрения различных поколений (выделения устойчивых и переменных элементов в нем) необходимо брать за основу картину мировосприятия взрослых, где «трансформирующая призма» уже обрела элементы устойчивости или консервации, и сравнивать его, напротив, с несформировавшимся до конца образом мира молодых людей.

Для апробации предложенных выше методологических принципов и инструментов исследования мы предполагаем провести исследование двух поколений. Первое в научной литературе традиционно обозначается как «советское поколение». Прекрасно осознавая внутреннюю неоднородность выделяемого для исследования объекта в силу хронологической, культурной и возрастной специфики людей в него входящих, мы намеренно объединяем в эту группу всех тех, кто не просто родился и вырос в СССР, но и однозначно признавал образ коммунизма в качестве идеальной картины благополучного будущего.

Второе поколение, чьи представления о будущем являются предметом нашего изучения, - поколение $\mathrm{Z}$ - молодые люди, родившиеся в начале 2000 -х гг., ключевые установки сознания которых формируются уже в условиях новой реальности, предполагающей отсутствие внешне внедряемых установок «советской модели». На наш взгляд, образ благополучия в сознании нового поколения, условно относимого к поколению Z, отражает именно такую переходную модель, для которой в полной мере характерны дуализм установок, лабильность «защитной оболочки». В качестве рабочей гипотезы мы допускаем, что формирование этой модели во многом есть следствие несформировавшейся «трансформирующей призмы» в условиях изменения новой идеологической парадигмы государства. В качестве предмета исследования выбран образ коммунизма как идеальной модели благополучия «советского человека».

Достижение этой цели поэтапно предполагает решение следующих задач:

- определение элементов «твердого ядра» и «защитной оболочки» в конструкции образа коммунистического будущего людей, относимых условно к «советскому поколению»;

- выявление изменившихся конструктов и оценок образа коммунизма новым поколением (поколением Z);

- обнаружение связи замеченных изменений со сменой идеологической парадигмы современного общества как одного из ключевых компонентов формирования «трансформирующей призмы».

Таким образом, проверка нашей гипотезы и решение поставленных задач предполагают использование методологии междисциплинарного синтеза. Решение задачи на первом этапе построено на базе анализа и сравнения исторических источников, предлагающих возможность воссоздания картины прошлого. Однако при изучении современного общества неизбежно возникает проблема взаимоотношений субъекта и объекта исследования. Другими словами, включенность исследователя в канву исторического времени может привести к существенному искажению при выборе и интерпретации фактов. Осознавая данное обстоятельство, на втором этапе намеренно предполагается использование другого метода, а именно социологического опроса, путем очного анкетирования респондентов, которые выбраны по принципу принадлежности к другому 
поколению, нежели авторы вопросов. Можно предположить, что такой организованный своеобразный диалог поколений позволит получить более ясную и четкую картину научного знания. И, наконец, на третьем этапе предполагается на основе использования сравнительного метода выявить связь не только элементов моделей благополучия разных поколений, но и влияние на их формирование господствующей идеологической парадигмы.

\section{Образ коммунизма в сознании советского человека}

Благополучие человека - явление во многом субъективное. Однако бытующие в обществе ценности, схемы восприятия реальности, устойчивые стереотипы задают вектор поиска личных и социальных устремлений, определяют критерии счастливой жизни. Следует предположить, что само благополучие является не просто некой конкретной и математически измеряемой величиной, а скорее индивидуальной или коллективной оценкой совпадения представления о счастье и благополучии с объективной реальностью, в которой существует человек. Советское государство было нацелено на построение коммунистического общества, которое, по мнению классиков марксизмаленинизма и их последователей, станет воплощением вселенской мечты человечества о счастье и благополучной жизни без войн и насилия. Разработанные К. Марксом и Ф. Энгельсом теоретические основы коммунизма, попав на благодатную русскую почву, дали соответствующие плоды. Идея создания совершенного мира своими корнями уходит в далекое прошлое [5]. Эсхатологические устремления русского народа, извечный поиск земли обетованной, вера в возможность нахождения в России «иконы Царства Божия» соединились с интеллигентскими конструкциями русских социалистов. Поиск цели жизненного пути, мечты о «хорошей жизни» получили конкретное выражение в вере в светлое будущее, которым стал коммунизм.

Однако образ коммунизма, отдельные штрихи которого набросал К. Маркс, и представления советских людей о рае на Земле не вполне совпадали, т.к. строились на тех реальных потребностях, удовлетворить которые обещали большевики во главе с В.И. Лениным, нацеленные на создание коммунистического общества. По К. Марксу, коммунизм не являлся целью человеческого развития, а лишь его формой. В этом отношении он не имел ничего общего с эсхатологией. К. Маркс писал: «Коммунизм есть необходимая форма и энергический принцип ближайшего будущего» [6, с. 127]. Это общество, в котором преодолено отчуждение человека от результатов его труда, в котором «свободное развитие каждого является условием свободного развития всех» [7, с. 447]. При коммунизме, писал К. Маркс, труд перестанет быть только средством для жизни, а сам станет первой его потребностью. «Когда вместе с всесторонним развитием индивидов вырастут и производительные силы, и все источники общественного богатства польются полным потоком..., и общество сможет написать на своем знамени: Каждый по способностям, каждому по потребностям!» [8, с. 20]. Таким образом, главной целью К. Маркса, его мечтой было освобождение человека от давления экономического принуждения, с тем чтобы он мог формировать себя как гармоничную всесторонне развитую личность.

В ходе практики социалистического строительства в СССР образ коммунизма, созданный К. Марксом, был существенно искажен, однако общегуманистическая направленность коммунизма, идея освобождения личности и сам образ коммунизма как мира благополучия остались в идеологических установках правящей партии. Программа КПСС давала такое определение коммунизму: «Коммунизм - это высокоорганизованное общество свободных и сознательных тружеников, в котором утвердится обще- 
ственное самоуправление, труд на благо общества станет для всех первой жизненной потребностью, осознанной необходимостью, способности каждого будут применяться с наибольшей пользой для народа» [9, с. 138].

Широкая панорама будущей счастливой жизни была впервые нарисована в Программе КПСС, принятой на XXII съезде в 1961 г. В ее основе лежала идея творческого преобразования мира, нацеленного на достижение высших идеалов добра, красоты и благополучия жизни. Смыслом нового общества становилось творческое преобразование мира: «научный поиск, вдохновение художника, тихие радости мыслителя, рекордная горячка спортсмена, рискованный эксперимент исследователя» [10, с. 13]. При этом счастье одного не могло быть отделено от счастья другого, поскольку человек всегда реализует себя вовне. В программе говорилось, что при коммунизме «утвердятся гармонические отношения между личностью и обществом на основе единства общественных и личных интересов» [11, с. 126], что предполагало постепенное превращение системы «социалистической демократии в высшую форму организации общества - коммунистическое общественное самоуправление» [9, с. 138].

По мере перехода от административного регулирования к самоуправлению, как виделось архитекторам нового мира, будет возрастать роль нравственных начал в жизни общества. Отсюда - наполненность коммунистической идеи этическим содержанием, которое легло в основание Морального кодекса строителя коммунизма. Его принципы противопоставлялись эгоизму буржуазного общества с его стремлением к наживе и извращенным формам наслаждения. Здесь были и любовь к Родине в сочетании с дружбой и братством народов, нетерпимость к врагам мира и свободы, нетерпимость к национальной и расовой неприязни. Документ включал и элементы религиозной морали. Высшей ценностью провозглашались добросовестный труд на благо общества и сознание общественного долга. Культивировавшиеся идеалы взаимного уважения людей друг к другу, коллективизма, товарищеской взаимопомощи нашли выражение в лапидарной формуле: «Человек человеку друг, товарищ и брат». Честность и правдивость, нравственная чистота, простота и скромность в общественной и личной жизни противопоставлялись таким порокам, как тунеядство, нечестность, карьеризм и стяжательство [11, с. 168-169].

Однако для рядовых граждан главным принципом коммунизма оставался лозунг «От каждого по способностям, каждому по потребностям», который прочитывался как возможность удовлетворять все свои материальные желания. В народе говорили о том, что будет бесплатный транспорт, бесплатные коммунальные услуги, столовые, а в дальнейшем вообще все предметы потребления станут бесплатными. Ведь в программе коммунистической партии прямо говорилось, что потребности людей будут удовлетворяться за счет общественных фондов [11, с. 126]. По сути, был взят курс на строительство общества потребления, что в полной мере отвечало запросам народа, выбор которого в 1917 г. был напрямую связан с острым желанием преодолеть нужду, голод и бесправие. Социализм родился из бедности и неустроенности жизни. Люди сражались, работали и умирали, чтобы построить общество достатка и благополучия. Они готовы были терпеть лишения, суровые условия жизни. Их не пугал тяжелый физический труд. Все должно было окупиться с лихвой в будущем, когда могучая воля человека переломит все трудности жизни и создаст новый мир, в котором не будет боли и страдания. Пафос энтузиазма социалистического строительства, наполненного верой в светлое будущее, готовность ради этого преодолеть все невзгоды весьма точно отразил поэт Владимир Маяковский: 
Свела промозглость корчею -

неважный мокр уют, сидят впотьмах рабочие, подмокший хлеб жуют.

Но шепот громче голода он кроет капель спад: «Через четыре года здесь будет город-сад!..

Здесь дом дадут хороший нам

и ситный без пайка, аж за Байкал отброшенная попятится тайга» [12].

И хотя материальные ценности не исчерпывали образ коммунизма, сосредоточенность на них, стремление преодолеть нужду и голод превращали изначально общегуманистическую доктрину, нацеленную на преодоление отчуждения личности и обретение ей свободы, в программу переустройства жизни через индустриальное развитие и наращивание технической базы с последующим справедливым распределением созданных совместным трудом возросших материальных благ. В этом отношении Великая мечта, по сути, сводилась к получению сугубо буржуазных, мещанских радостей жизни. На это одним из первых еще задолго до революции 1917 г. обратил внимание Н.А. Бердяев. Он сравнивал социализм с религией, ориентированной на построение «земного рая», в котором все волнующие человека вопросы сводятся к хлебу насущному. Стремление к коммунизму не противоречило традиционным буржуазным принципам организации жизни. Окончательное благополучное устроение мира на основе мещанских ценностей сытой жизни для всех, а не некоторых, как было ранее, стало фокусом всего социалистического мировоззрения [13]. В том же ключе рассуждал С.Н. Булгаков, увидевший в социалистической революции оргию хищничества с ее животными мещанскими инстинктами [14]. И хотя базовые потребности населения к середине $\mathrm{XX}$ в. в целом были удовлетворены, запрос на полное удовлетворение уже статусных, претенциозных и иных потребностей остался.

Образы коммунизма различались в разные периоды советской истории. Как пишет И.В. Желтикова, в первые годы после Октябрьской революции коммунистический образ будущего наполнялся больше утопической экспрессией, чем реальными чертами. «Это был не столько проект, сколько мечта, неслучайно одним из его выразителей становится поэзия» [15, с. 100]. В 1922 г. русская революционерка Александра Колонтай в своем рассказе «Скоро (через 48 лет)» так представляла себе коммунизм: «Среди всей собравшейся на праздник елки молодежи коммуны не было ни одного больного, бледного, изнуренного лица. Ярко блестели задором пытливые глаза; смелы, гибки и ритмичны были движения их упругих, юных тел... Молодежь «Десятой коммуны» любила жизнь, любила смех и хмурилась только тогда, когда ей предстояло вступать в бой с единственным оставшимся у человечества врагом - с природой. Но хмурилась она не потому, что борьба была ей не по сердцу, но чтобы лучше сосредоточиться и избрать лучший путь для одоления врага... Без этой борьбы скучно стало бы жить в коммуне. Жизнь налажена и катится по разумно заведенному порядку. У всякого своя специальность и свое любимое дело. «Специальностью» называется та работа, которую член коммуны выполняет в те два часа в день, когда его силы используются для коммунального хозяйства. Остальное время каждый отдает свои силы любимому роду работы: науке, технике, искусству, усовершенствованному полеводству, преподаванию. 
И жизнь налажена так, что живут не семьями, а расселяются по возрастам. Дети - в «Дворцах ребенка», юноши и девочки-подростки - в веселых домиках, окруженных садами, взрослые - в общежитиях, устроенных на разные вкусы, старики - в «Доме отдыхновения». В коммунах нет ни богатых, ни бедных; эти слова - забытые слова. У членов коммуны имеется все, что надо для того, чтобы не думать о насущном, о материальном. Одежду, пищу, книгу, развлечения - все доставляет члену коммуна. За это член коммуны отдает коммуне свои рабочие руки на два часа в день и свое творчество, пытливое искание своего ума - во все остальное время своей жизни» [16].

В годы хрущевской оттепели власть конкретизировала жизненные ориентиры и партийные установки. В пропагандистской литературе коммунизм предстает светлым и удобным обществом будущего. Был провозглашен курс на всестороннее удовлетворение растущих потребностей советских трудящихся. В качестве идеала, по сути, был взят средний класс западного буржуазного общества с его высокими стандартами потребления. Советские граждане обрели личное пространство, было легитимировано их стремление к приобретению личных вещей [17]. «Предоставить каждому члену общества материальные и культурные блага по его растущим потребностям, индивидуальным запросам и вкусам» - такое требование к будущему предъявлялось в программе КПСС [11, с. 126]. Однако речь не шла о построении общества анархии, безделья и праздности. Считалось, что благодаря применению высокоэффективных технических средств и технологий материальные блага польются полным потоком в таком объеме, что всем хватит, чего только душа пожелает. «Каждый будет участвовать в общественном труде и обеспечивать непрерывный рост материальных и духовных богатств общества...Благодаря высокому уровню сознательности, разовьется внутренняя потребность добровольно и по своим склонностям трудиться для общественного блага» [11, с. 127]. Труд не будет в тягость человеку, а как потребность здорового организма превратится в подлинное творчество и источник радости.

Мечта о материальном изобилии поначалу уживалась с такими нравственными принципами, как честность, добросовестность и коллективизм. Благополучие без стяжательства казалось вполне достижимым. «Облик погрязшего в плюшевых абажурах обывателя не нравился никому» [10, с. 14]. Идея достатка и материального благополучия в коммунистической идеологии была глубоко враждебна консьюмеризму. Потребительство, вещизм не могли и не должны были стать смыслом нового общества. Материальный интерес должен был остаться в прошлом [18, p. 29-30]. Для коммунистической идеологии это стало серьезной моральной проблемой. Власть так и не смогла ее разрешить, пытаясь принимать порой взаимоисключающие меры. Пропагандируя с одной стороны рост уровня жизни, партия всячески дискредитировала ценности материального благополучия и на практике стремилась ограничить рост потребления $[19$, c. 89].

Коммунизм стал эсхатологической мечтой, в которую каждый вкладывал то, что его волновало. Образ коммунизма всегда оставался туманным, но наполненным светлыми красками. В нем сфокусировался мир безграничного счастья, волшебства и вечного праздника. Его сложно было конкретизировать, но вера в него придавала жизни смысл. Василий Аксенов, будущий диссидент, разочаровавшийся впоследствии в социалистических идеалах, писал: «В детстве коммунизм представлялся мне так. Утром нас будят не будильники, а звенящие звуки фанфар. Вскочив с постели и, конечно, не заметив вначале волшебного изменения нашей квартиры, мы распахиваем окна и видим чудесно преображенный за одну ночь, прекрасный, торжественный и трепещущий мир. По радио объявляют, что начался коммунизм. И все-таки счастье наше, что у нас была 
вера в это волшебство, вера в то, что за нарисованным очагом в каморке папы Карло действительно лежит прекрасная волшебная страна» [20, л. 2a].

При коммунизме, считалось, не будет различий между городом и деревней, не будет денег, не будет преступности. Человечество станет единым, национальные границы уйдут в прошлое. Столицей Земли мыслилась только Москва. Перемещение между разными частями света будет осуществляться бесплатно и, благодаря науке и новым технологиям, чрезвычайно быстро. Самые отчаянные фантазеры говорили, что при коммунизме появятся видеотелефоны. Дороги для пешеходов станут самодвижущиеся, а трактора, поезда и автомобили будут ездить без водителя. Не нужно будет мыть посуду и стирать белье, за человека это сделает техника. Всю физическую работу возьмут на себя машины; роботы будут наливать напитки в стаканы и подавать еду. Продолжительность человеческой жизни достигнет 200-300 лет, кто-то говорил о достижении бессмертия.

Одни мечтали о воплощении лучших романтических порывов на основе любви, красоты и верности Родине. Другие размышляли о свободном столике в ресторане и отдельной квартире. «Нигде не скажут «нет мест». Задумал жениться - мать не спросит с удрученным видом: «А где жить-то будете?» [10, с. 17]. Не удивительно, что публикация программы будущей жизни в газете «Правда» вызвала колоссальный интерес. Новую Программу КПСС подавляющее большинство опрошенных в то время назвали главным документом XX века. [21]. Только за полтора месяца (с 1 августа по 15 сентября 1961 г.) на партийных конференциях, собраниях, посвященных обсуждению этого документа, присутствовало почти 44 млн человек, а выступило около 3,5 млн. В ЦК, обкомы, крайкомы КПСС, редакции центральных и местных газет, на радио и телевидение поступило 170801 письмо, из которых 40733 было опубликовано [22, с. 292]. В этих письмах в полной мере отражены мечты и чаяния советских людей. Преобладающими в них были идеи материального насыщения и социальной справедливости на основе эгалитарных и коллективистских ценностей.

В конце 1990-х гг., когда в моде была демонизация советского прошлого, среди части населения, хорошо помнившей начало 1960-х гг., проводился опрос. Несмотря на то, что воспоминания о былом невольно искажаются современными негативными оценками, абсолютное большинство респондентов призналось, что верило в коммунизм. Сомневались или не верили 18-24 \% [23]. При этом, по данным Института общественного мнения, существовавшем в 1960-1967 гг., все участники опроса практически стопроцентно выражали свою верность идеалам и практикам коммунизма [21].

А.А. Фокин предложил разделить позитивное отношение к коммунизму на две большие группы. Первая связывала коммунизм с уравнительными тенденциями. Вторая воспринимала коммунизм сугубо потребительски, как «кормушку» бесплатных благ. И именно эта версия коммунизма была преобладающей $[24$, с. $122,123,135]$. При обсуждении программы КПСС встречались предложения со временем передать в пользу общества частные дома, дачи, автомобили, поскольку при коммунизме, когда все потребности населения в организации отдыха, досуга будут удовлетворены, необходимость решать жизненные задачи в рамках индивидуальных стратегий полностью отпадет. Программа коммунистического строительства не предполагала выпускать большое количество автомобилей. Иметь собственную машину при коммунизме считалось такой же нелепостью, как иметь собственный поезд или собственный театр. Общественные автомобили и дачи будут использоваться более эффективно, чем частные, т. к. освободят рядового пользователя от проблем, связанных с их обслуживанием. А время, сэкономленное за счет использования общей собственности, можно будет использовать для развития индивидуальных способностей [22, с. 299-300]. 
В представлениях о коммунизме в конечном счете на первое место вышло то, что изначально было заложено в социалистической идее, - желание накормить народ. «КПСС ставит задачу всемирно-исторического значения - говорилось в программе партии - обеспечить в Советском Союзе самый высокий жизненный уровень по сравнению с любой страной капитализма» [11, с. 147]. Но если капитализм культивировал и насаждал конкретные желания, предлагал конкретные товары и услуги, то социализм пробуждал желание, но не фокусировал его. И вместо создания потребительского рая и рекламы поддерживал созданные желания систематическими лишениями [25]. Мечта, сводимая к задачам экономического развития, успешно решаемая в рамках критикуемой капиталистической системы, неизбежно переориентировала основную часть населения в сторону буржуазного Запада, тем самым предопределив крушение СССР. Именно неспособность выполнить свои обещания относительно проблем материального благополучия способствовала падению советской системы», - считает Т. Вихавайнен $[18$, p. 52]. Однако уровень жизни советских людей в 1970-е гг. существенно вырос. В этом отношении власть сложно в чем-то упрекнуть. Парадокс ситуации заключался в том, что верность коммунистическим идеалам, готовность защищать свою Родину перед лицом сытого Запада были наиболее высоки, когда уровень жизни советских людей был минимален и благодарить коммунистическую партию было еще не за что. Когда же партия стала выполнять свои обещания и сделала жизнь советского человека относительно благополучной, любовь к ней испарилась, и вместо благодарности она получила от советского человека непрерывные насмешки и нескрываемое презрение. Трагедия коммунизма заключалась в том, что путь к «светлому будущему» шел через формирование этики потребления, что кардинально изменило отношение граждан к государству и, в конечном счете, стимулировало крушение коммунистического проекта [26].

Таким образом, «твердое ядро» «трансформирующей призмы» советского человека - это смесь общечеловеческих ценностей, желаний и установок, дополненная идеями коллективизма, свободы, равенства, братства. Одним из ключевых элементов этой системы установок выступает, в том числе, и естественное для человека желание материального благополучия. В качестве защитной оболочки этого «твердого ядра» выступали образы, идеи и установки, усиленно внушаемые пропагандистской машиной государства. Внедряемые системой по сути религиозные принципы терпения, веры в неизбежное светлое будущее после победы над всеми врагами ослабляли или вообще затирали существующий когнитивный диссонанс в сознании в результате явного несоответствия между реальностью и представлением о нем. Именно поэтому в целом, пока сама идеология представляла собой непротиворечивую модель и государственная пропаганда работала без сбоев, «советский человек» был удовлетворен существующим положением дел и был счастлив. Но изменение вектора идеологического влияния, ослабление самой государственной машины обработки сознания привели к прямому взаимодействию «твердого ядра» и реальности и вызвало фрустрацию в масштабах всего российского общества. Возможно, именно этим объясняется широкое распространение деструкции в России в 1990-е гг.

При этом изменения коснулись не только окружающей действительности: главное изменение произошло в сознании людей. «Трансформирующая призма», созданная десятилетиями идеологической и воспитательной работы со стороны государства, которая позволяла чувствовать себя удовлетворенным и счастливым даже при отсутствии достижения личного материального благополучия, основанная лишь на вере в будущее, претерпела трансформацию. В постсоветской России была поставлена новая задача: решительно и бескомпромиссно преодолеть унылое наследие советского тоталитарного 
прошлого и, ориентируясь на Запад, как идеал, провести рыночные реформы, наполнить прилавки магазинов качественными разнообразными товарами и достичь материального изобилия, о котором когда-то писали в программе КПСС. Однако процесс трансформации общественной модели очень быстро вышел из-под контроля государства. Старая идеология была целенаправленно уничтожена вместе с гегемонией партии, а новая не была создана. По сути, повсеместно исчезла воспитательная работа. $\mathrm{B}$ «трансформирующей призме» общественного сознания образовался вакуум, который очень быстро был заполнен противоположной по знаку информацией. По данным Всемирного исследования ценностей, уровень счастья и удовлетворенность жизнью упали катастрофически [27].

Но главное последствие проявилось позже: поколение взрослых людей, которое прошло через все трудности 1990-х гг. и на которое пришелся основной удар крушения системы, единолично попыталось создать «защитную оболочку» из новых ценностей и установок для следующего поколения. Государство было настолько ослаблено и растеряно, что говорить о наличии какой-то модели целенаправленного идеологического воздействия в эти годы вряд ли приходится.

\section{Оценка новым поколением (поколением Z) образа коммунизма}

Поскольку «трансформирующая призма» современного поколения (поколения Z, или хоумлэндеров, к которым относят родившихся в 2003 г. и позже [28]) сформировалась в особых условиях трансформации системы, ключевой гипотезой проведения второго этапа нашего исследования является утверждение, что современная молодежь должна обладать и базисными элементами «твердого ядра» «советского поколения», и элементами «защитной оболочки», сформированной в 1990-е гг., благодаря передаче жизненного опыта родителей. Более того, в ней должны также присутствовать дуалистичные оценки и элементы.

Для выявления и понимания связи основных элементов, установок и стереотипов современного поколения молодежи с опытом предыдущего поколения в рамках анкетирования было предложено выразить представление об образе будущего «поколения советских людей», что должно было подтвердить или опровергнуть гипотезу о наличии связи существующего образа благополучной жизни со сменой идеологической парадигмы современного общества.

В качестве исследуемого объекта были выделены студенты первых-вторых курсов вузов г. Томска, которые соответствуют качественным критериям отнесения их к поколению Z. Выборочная совокупность была сформирована методом простой бесповторной вероятностной серийной (гнездовой) выборки, в рамках которой было проведено сплошное исследование путем анкетирования рандомно выделенных студенческих групп первого-второго курса. Количественный объем выборки составил величину 80 человек, подавляющее большинство (89 \%) которых относилось к возрасту 17-19 лет (2003-2004 годы рождения). Основной целью опроса было выявление трансформационных элементов в субъективной модели благополучия как следствие смены идеологической составляющей общественной парадигмы на основе анализа субъективного отношения респондентов к модели «благополучного общества» предыдущего поколения.

Опрос проводился в два этапа: чтобы исключить возможную «подсказку» или непроизвольное влияние содержащихся в вопросах 4-6 формулировок на ответы первых трех вопросов, анкетируемым предлагалось ответить сначала на вопросы 1-3, затем полученные ответы собирались и только после этого выдавалась вторая часть анкеты с последующими вопросами. Вопросы первого блока озвучивались вслух по очереди, 
респонденты должны были на них также отвечать, не зная последующих вопросов. Вопросы второго блока были представлены уже в письменной форме, и анкетируемые имели возможность видеть все вопросы сразу, что позволяло им самим коррелировать собственные ответы, чтобы избежать в них противоречия. Кроме того, каждый блок вопросов содержал так называемые вопросы-ловушки, формулировки которых должны были посеять у испытуемых сомнения в истинности предыдущего ответа и тем самым проявить неустойчивые или дуалистичные компоненты в общей картине мировосприятия.

Анкетирование проводилось анонимно, единственными вопросами, персонализирующими данные, были вопрос о годе рождения, что объяснимо первичной концепцией исследования, и дополнительный вопрос о гендерной принадлежности опрашиваемых для возможного продолжения научного поиска в этом направлении.

Результаты опроса получены следующие. Первый вопрос предлагал без дополнительных уточнений высказать свое отношение к идее коммунизма как таковой. В данном случае по факту оценивалась первая реакция на слово «коммунизм». Полученные результаты свидетельствуют о преобладании в целом негативной реакции: 77,2 \% (против $18,9 \%$ ) заявило, что при коммунизме жить не хотело бы, почти $5 \%$ анкетируемых не смогло однозначно ответить на этот вопрос. Интересен факт того, что предложение оценить напрямую образ коммунизма (вопрос 2) дает несколько иную картину: образ коммунизма скорее негативно оценили 52 \%, тогда как позитивная оценка дана 34,2 \% респондентов, при том, что количество неопределившихся возросло более чем в два раза - до $12,7 \%$. Возможное объяснение этому в том, что, по-видимому, трактовка образа коммунизма в сознании анкетируемых абстрагируема от возможности своего существования в нем. Возрастание количества неопределившихся, в свою очередь, предположительно объяснимо возникшей дилеммой: например, «жить при коммунизме не хочу», но при этом вроде как «образ положительный» или наоборот. Третий вопрос, в котором опрашиваемым предлагается назвать ассоциации, связанные с понятием «коммунизм», вносит окончательную ясность в понимании возникшего противоречия в рамках данного психологического эксперимента, т. к. здесь и сталкивается «образ идеального общества» со своим преломлением через «трансформирующую призму» воспитания и идеологии. Стоит заметить, что такой компонент «призмы», как социальный опыт, здесь будет отсутствовать или иметь минимальное влияние, т. к. новое поколение не успело пожить даже в рамках социализма. Поэтому все ассоциации у него изначально являются навязанными извне, как результат негативно оцениваемого жизненного опыта предыдущего поколения и изучения общественных предметов в школе.

Все полученные ассоциативные ряды можно разбить на ряд групп:

1. Негативные. Среди наиболее часто встречаемых ассоциаций: «репрессии», «жестокость», «доносы», «отсутствие свободы», «цензура», «ГУЛАГ», «дефицит», «уравнительность в распределении благ».

2. Позитивные. Наиболее часто встречаемая ассоциация - «равенство» (17 респондентов), затем идут «коллективизм», «отсутствие безработицы», «справедливость», «светлое будущее».

3. Объектно-персонифицированные: «СССР», «плановая экономика», «Ленин», «Сталин», КПРФ.

И, наконец, наибольший интерес вызывают так называемые «эмоционально окрашенные ассоциации»: «утопия», «далекое прошлое», «одинаково и неинтересно», «грусть, печаль скука», «холод», «голод», «плохо». Условно к данной категории можно отнести и ответы респондентов, у которых вообще не возникло никаких ассоциаций или отказ их искать (10\% респондентов) 
Именно они, на наш взгляд, наглядно доказывают неестественность, навязанность, отчужденность картинки «коммунистического образа мира» для данного поколения, поэтому она представляется им неинтересной и скучной. И вновь сравнение ответов теперь уже на второй и третий вопрос приводит к выявлению когнитивного диссонанса у значительной части респондентов: многие из тех, кто в целом оценивает образ коммунизма скорее как позитивный, используют негативный ассоциативный ряд для его описания, и наоборот. Налицо дуализм оценки «образа», который возникает из противоречия: его строили, к нему стремились поколения предков, значит, он должен быть позитивный, но исходя из полученных знаний на уроках истории и информации из СМИ он злой и плохой, а поскольку он уже в прошлом, можно не задумываться об этом противоречии.

Второй блок вопросов начинается с вопроса «Опишите кратко образ желаемого будущего. В каком обществе Вы хотели бы жить?». Данный вопрос нужен для определения ключевых элементов образа будущего у анкетируемых и последующего составления их модели благополучия. Анализ ответов показал, что свобода является ключевой категорией, что находит свое выражение не только в частом употреблении данного термина при описании воображаемого будущего, но и косвенно: при описании властных отношений в будущем обществе. Вообще тема взаимоотношений человека и государства является одной из самых популярных среди респондентов. И хотя само описание будущего аппарата управления весьма разнообразно - от весьма расплывчатого «эффективного и сменяемого правительства» и «государство прислушивается к мнению граждан» до указания конкретных форм правления «меритократии», «либерализма», «демократии» и даже «анархизма» - в целом очевиден запрос на минимизацию роли и подконтрольность государства обществу. Будущее общество мыслится молодым поколением как общество «развитых информационных технологий» с «открытыми границами», «терпимостью» и «толерантностью» к другим людям. Последние две категории из упомянутых выше встречаются также часто, как «социальное равенство», «справедливость», «отсутствие бедных». Однако интересно, что выражение «бесплатная медицина и образование» встречается всего один раз, тогда как «доступная медицина и образование» звучит гораздо чаще. Еще одна часто встречающаяся повторяемость, обнаруженная в анкетах, - запрос на общество без войн, коррупции и преступности, что фиксируется как непременный атрибут будущего практически в каждой десятой анкете. С другой стороны, описание будущего общества как появление возможности для самореализации или саморазвития обнаруживается только в трех ответах.

Следующий вопрос представлял собой своеобразную «ловушку» для участников опроса. Анкетируемым было дано краткое описание коммунистического образа будущего, стандартно указываемого в программах КПСС (без указания на источник), а именно как «общества, в котором утвердятся подлинная демократия и общественное самоуправление, люди будут свободные, а труд на благо общества станет для всех первой жизненной потребностью, способности каждого будут применяться с наибольшей пользой для народа, и сам человек будет получать от общества столько, сколько пожелает». Респондентам предлагалось ответить на вопрос: «Хотели ли бы они жить в таком обществе?». Рабочая гипотеза предполагала, что практически все ответят положительно, т. к. представленный образ содержит в принципе общечеловеческие, гуманистические черты. Действительно, большинство ответило «да», но их было только 59 \% опрошенных, а 40 \% ответило «нет». И подобный результат становится весьма логичным при анализе ответов на последний вопрос: «Можно ли построить такое общество, как описано в вопросе 5 или это чистая утопия?», где $84 \%$ анкетируемых признает, что это 
утопия. Таким образом, все встает на свои места: да, возможно, описание коммунистического общества и выглядит весьма привлекательно, но нет смысла даже пытаться что-то делать для его создания, потому что оно изначально утопично и невозможно. Кроме того, в силу недостижимости такого рода будущего происходит «приземление» потребностей. От потребностей более высокого уровня наблюдается переход к потребностям более низкого - теперь на первое место выходит не столько индивидуальное самораскрытие, сколько прагматичное использование имеющихся в наличии ресурсов.

Итак, проведенное исследование обнаружило множество парадоксальных, казалось бы, фактов. Опрос выявил преимущественно негативный образ коммунизма. От прежних преставлений о коммунизме, как мире достатка и благополучия, не осталось и следа. Идеализированный образ светлого будущего трансформировался в стереотипный образ прошлого, оцениваемый преимущественно негативно. Даже те, у кого коммунизм вызывает позитивные ассоциации (стабильность, справедливость, хорошее образование), однозначно связывают его не с будущим типом общественной организации, а исключительно с прошлым. При этом образ коммунистического общества, существовавший в советские годы, по-прежнему остается весьма привлекательным. Термин «коммунизм» приобрел иное значение, но сами идеалы не претерпели существенных изменений. Потребность в светлом будущем, в котором не будет войн и нищеты, мечты о наступлении мира социальной гармонии и справедливости, свободы и добра остались прежними.

Таким образом, на лицо сохранение основных компонентов «твердого ядра», которое, однако облачено в совершенно иную «защитную оболочку». И эта защита весьма неустойчива сама по себе. Существование дуальных элементов в ней вызывает внутренний диссонанс. Судя по предпочтениям и ожиданиям относительно будущего, новое поколение также пытается найти равновесие, примирив реальность и идеалистический образ, но на данный момент этого нет, что и объясняет печальные эмоционально окрашенные образы у некоторых респондентов, страх перед неизвестным будущим и чувство неудовлетворенности прошлым и настоящим. Наличие пробелов в «защитной оболочке» приводит на данном этапе к частичному разрушению и «твердого ядра». В частности, мотивация на уровне Growth (личностный рост, саморазвитие) уже не доминирует в сознании современной молодежи. Проблема материального выживания, существовавшая в 1990-е гг., генетически перетекла из опыта их родителей. И даже дуалистичность и противоречивость оценки прошлого опыта не являются чем-то непонятным, если обратиться к стандартным учебникам истории, по которым училось современное поколение молодежи.

На смену строго выверенным, вычитанным и контролируемым партией жестко идеологизированным учебникам общественных дисциплин советского периода в 1990-е гг. пришло огромное разнообразие авторов и изданий с зачастую диаметрально противоположными оценками одних и тех же событий. Это привело не только к растерянности учителей и преподавателей, но и, как следствие, весьма противоречивому изложению ими исторического материала.

\section{Заключение}

Таким образом, проведенное исследование показало, что в силу неоднозначности даже самой терминологии, используемой при изучении феномена благополучия, наибольшей инструментальностью будут обладать исследования на стыке различных дисциплин. Междисциплинарный подход позволяет выявить не только очевидные причинно-следственные связи, но возможно скрытые от ученого смыслы. Использование опы- 
та исторического исследования, наряду с инструментальным аппаратом социологических и психологических изысканий, в нашем случае позволило выявить набор постоянных и переменных компонентов, формирующих поколенческий образ благополучия. Использование исследований Альдерфера, Герцберга, методологических приемов Лакатоса помогло выявить и описать механизм действия «трансформирующей призмы». В ходе апробации модели «трансформирующей призмы» были исследованы элементы «твердого ядра», «защитной оболочки» поколения «советских людей» и поколения Z, где подтвердилась гипотеза о том, что «твердое ядро» практически не претерпевает изменений в отличие от «защитной оболочки», которая формируется под воздействием воспитания, идеологии и собственного жизненного опыта. На основе анализа выявлено, что для молодого поколения с минимальным жизненным опытом основными формирующими факторами будут являться последние два. Приведенное исследование трансформации образа коммунизма в сознании исследуемых поколений показало, что именно действие «трансформирующей призмы» приводит к искажению восприятия окружающего мира, вследствие чего созданная сознанием субъективная картина (в нашем случае образ благополучия) может существенно отличаться от реальности. Это обстоятельство, в свою очередь, приводит к деформации оценки и парадоксальному, с точки зрения стороннего наблюдателя, состоянию удовлетворенности или, напротив, неудовлетворенности. Таким образом, предложенная в нашем исследовании модель «трансформирующей призмы» может рассматриваться как дополнительный инструмент научного понимания и способов решения одной из самых актуальных проблем современного общества - проблемы благополучия.

\section{СПИСОКЛИТЕРАТУРЫ}

1. Alderfer C.P. Existence, relatedness, and growth; human needs in organizational settings. - New York: Free Press, 1972. - $198 \mathrm{p}$.

2. Herzberg F., Mausner B., Snyderman B.B. The motivation to work. 2nd ed. - New York: JohnWiley, 1959. - $157 \mathrm{p}$.

3. Двухфакторная модель Герцберга. URL: https://hrhelpline.ru/modeli-motivatsii-na-paltsahdvuhfaktornaya-model-gertsberga/ (дата обращения 01.10.2021).

4. Lakatos I. Falsification and the methodology of scientific research programmes // Criticism and the growth of Knowledge / Eds. I. Lakatos, A. Musgrave. - Cambridge: Cambr. University Press, 1970. - P. 91-195.

5. Виноградова Н. Образ светлого будущего в советском общественном сознании // Русская культура под знаком революции. Дальний Восток, близкая Россия. - Белград; Сеул; Сайтама: Логос, 2018. C. $125-138$.

6. Маркс К. Экономико-философские рукописи 1844 г. // Сочинения. - М.: Издательство политической литературы, 1974. - Т. 42. - С. 41-174.

7. Маркс К., Энгельс Ф. Манифест Коммунистической партии // Сочинения. - М.: Издательство политической литературы, 1955. - Т. 4. - С. 419-459.

8. Маркс К. Критика Готской программы // Сочинения. - М.: Издательство Политической литературы, 1961. - T. 19. - С. 9-32.

9. Программа Коммунистической партии Советского Союза // Материалы XXVII съезда Коммунистической партии Советского Союза. - М.: Политиздат, 1986. - С. 121-187.

10. Вайль П., Генис А. 60-е. Мир советского человека. - М.: Новое литературное обозрение, 2001. - 368 с.

11. Программа Коммунистической партии Советского Союза // КПСС в резолюциях и решениях съездов, конференций и Пленумов ЦК. - М.: Политиздат, 1986. - Т. 10. - С. 81-185.

12. Маяковский В. Рассказ Хренова о Кузнецкстрое и о людях Кузнецка. URL: https://www.culture.ru/poems/21289/rasskaz-khrenova-o-kuzneckstroe-i-o-lyudyakh-kuznecka (дата обращения 01.10.2021).

13. Бердяев Н.А. Социализм как религия // Вопросы философии и психологии. - 1906. - Кн. V (85). С. 508-545.

14. Булгаков С.Н. Христианство и социализм // Булгаков С.Н. Героизм и подвижничество. - М.: Русская книга, 1992. - С. 210-253. 
15. Желтикова И.В. Когда наступает будущее? Образы будущего России второй половины 20 века // Международный журнал гуманитарных и естественных наук. - 2018. -№ 8. - С. 99-106.

16. Колонтай А. Скоро (через 48 лет). URL: http://www.fedy-diary.ru/aleksandra-kollontaj-rasskazy-povestlyubov-trekh-pokolenij/ (дата обращения 01.10.2021).

17. Гурова О. От бытового аскетизма к культу вещей: идеология потребления в советском обществе // Люди и вещи в советской и постсоветской культуре. - Новосибирск: Изд-во Новосиб. гос. ун-та, 2005. - C. 6-21.

18. Communism and consumerism: the Soviet alternative to the affluent society / Eds. T. Vihavainen, E. Bogdanova. - Leiden: Brill, 2015. - 172 p.

19. Синицын Ф.Л. Формирование «общества потребления» в СССР: идеологический вызов для власти (1964-1982 гг.) // Вестник ВолГУ. Серия 4. История. Регионоведение. Международные отношения. 2021. - Т. 26. - № 3. - С. 84-94.

20. Российский государственный архив литературы и искусства (РГАЛИ). - Ф. 2924. - Оп. 2. - Д. 1319.

21. Грушин Б.А. Четыре жизни России в зеркале опросов общественного мнения: очерки массового сознания россиян времен Хрущева, Брежнева, Горбачева и Ельцина. - М.: Прогресс-Традиция, 2001. $624 \mathrm{c}$.

22. Пыжиков А.В. Хрущевская «оттепель». - М.: Олма-Пресс, 2002. - 509 с.

23. Аксютин Ю.В. Хрущевская «оттепель» и общественные настроения в СССР в 1953-1964 гг. - М.: РОССПЭН, 2004. - $486 \mathrm{c}$.

24. Фокин А.А. «Коммунизм не за горами»: образы будущего у власти и населения СССР на рубеже 1950-1960-х годов. - М.: Политическая энциклопедия, 2017. - 221 с.

25. Verdery K. What was socialism, and what comes next? - Princeton, NJ: Princeton University Press, 1996. $312 \mathrm{p}$.

26. Chernyshova N. Soviet consumer culture in the Brezhnev Era. - London, New York: Routledge, 2013. $280 \mathrm{p}$.

27. Development, freedom and rising happiness: a global perspective (1981-2007) / R. Inglehart, R. Foa, R. Peterson, C. Welzel // Perspectives on Psychological Science. - 2008. - V. 3. - № 4. - P. 277-278.

28. Богачева Н.В., Сивак Е.В. Мифы о «поколении Z». - М.: НИУ ВШЭ, 2019. - 64 с.

Поступила 08.10.2021 2. 
UDC 330.12:330.59:316.323

\title{
SPECIFICITY OF FORMATION AND TRANSFORMATION OF ASSESSMENT OF PUBLIC WELL-BEING IN THE CONTEXT OF INTERDISCIPLINARY RESEARCH OF COMMUNISM IMAGE
}

\author{
Maxim S. Petrenko ${ }^{1,2}$, \\ petmaxim@yandex.ru \\ Sergey A. Dukart $3,4,5$, \\ dukart@mail.ru \\ 1 Novosibirsk State University of Economics and Management, \\ 52/1, Kamenskaya street, Novosibirsk, 630099, Russia \\ 2 Novosibirsk Law Institute (branch) of Tomsk State University, \\ 7, Sovetskaya street, Novosibirsk, 630007, Russia \\ 3 National Research Tomsk Polytechnic University, \\ 30, Lenin avenue, Tomsk, 634050, Russia \\ ${ }_{4}^{4}$ West-Siberian Branch Russian State University of Justice, \\ 2, Lenin square, Tomsk, 634050, Russia \\ 5 State University of Control Systems and Radioelectronics, \\ 40, Lenin avenue, 634050, Tomsk, Russia
}

Maxim S. Petrenko, Cand. Sc., associate professor, Novosibirsk State University of Economics and Management; Novosibirsk Law Institute (branch) of Tomsk State University.

Sergey A. Dukart, Cand. Sc., associate professor, National Research Tomsk Polytechnic University; WestSiberian Branch Russian State University of Justice; State University of Control Systems and Radioelectronics.

The article analyzes the transformation of the image of a prosperous future from the "Soviet generation» to the «Z» generation. The relevance of the study is caused by the need to understand the specifics of the formation of an assessment of the well-being state and its relationship with the motivation and activity of the modern generation. The purpose of this study is to develop and approbate methodological tools for studying the problem of well-being. Methods. The basic of the research is the methodology of interdisciplinary synthesis. Based on the theories of K. Alderfer and K. Herzberg, the authors interpret the relation between the changes in the basic motivation of society and changes in the basic elements of the image of the future. The description of the "transforming prism» model allows one to determine the causes of contradictions in scientific research when assessing the picture of well-being. The image of communism and its significance in assessing the well-being of people belonging to the «Soviet generation» are investigated on the basis of the historical method. With the help of a sociological survey, the key components of the image of the future of «Z» generation are identified. Comparative analysis allows us to assess the correctness of the application of the «transforming prism» model to understand the reasons for individual elements of the desired model of wellbeing. Results. The use of the methodology of interdisciplinary synthesis can significantly expand the horizons of scientific knowledge. The application of the «transforming prism» model allows one to draw more accurate and correct conclusions regarding the nature of constant and variable elements in the image of the well-being of the studied generation.

Key words: Well-being, «transforming prism», model, motivation, communism, image of the future 


\section{REFERENCES}

1. Alderfer C.P. Existence, relatedness, and growth; human needs in organizational settings. New York, Free Press, 1972. 198 p.

2. Herzberg F., Mausner B., Snyderman B.B. The motivation to work. $2^{\text {nd }}$ ed. New York, John Wiley, 1959. $157 \mathrm{p}$.

3. Dvukhfaktornaya model Gertsberga [Two-factor Herzberg model]. Available at: https://hrhelpline.ru/ modeli-motivatsii-na-paltsah-dvuhfaktornaya-model-gertsberga/ (accessed 1 October 2021).

4. Lakatos I. Falsification and the methodology of scientific research programmes. Criticism and the growth of Knowledge. Eds. I. Lakatos, A. Musgrave. Cambridge, Cambr. University Press, 1970. pp. 91-195.

5. Vinogradova N. Obraz svetlogo budushchego v sovetskom obshchestvennom soznanii [The image of a bright future in the Soviet public consciousness]. Russkaya kultura pod znakom revolyutsii. Dalniy Vostok, blizkaya Rossiya [Russian culture under the sign of revolution. Far East, close Russia]. Belgrad, Seul, Saitama, Logos Publ., 2018. pp. 125-138.

6. Marks K. Ekonomiko-filosofskie rukopisi 1844 g. [Economic and philosophical manuscripts of 1844]. Sochineniya. Moscow, Izdatelstvo politicheskoy literatury Publ., 1974. Vol. 42, pp. 41-174.

7. Marks K., Engels F. Manifest Kommunisticheskoy partii [Communist Manifesto]. Sochineniya. Moscow, Izdatelstvo politicheskoy literatury Publ., 1955. Vol. 4, pp. 419-459.

8. Marks K. Kritika Gotskoy programmy [Criticism of the gothic program]. Sochineniya. Moscow, Izdatelstvo Politicheskoy literatury Publ., 1961. Vol. 19, pp. 9-32.

9. Programma Kommunisticheskoy partii Sovetskogo Soyuza [Program of the Communist Party of the Soviet Union]. Materialy XXVII sezda Kommunisticheskoy partii Sovetskogo Soyuza [Materials of the XXVII Congress of the Communist Party of the Soviet Union]. Moscow, Politizdat Publ., 1986. pp. 121-187.

10. Vayl P., Genis A. 60-e. Mir sovetskogo cheloveka [1960th. The world of the Soviet man]. Moscow, Novoe literaturnoe obozrenie Publ., 2001. 368 p.

11. Programma Kommunisticheskoy partii Sovetskogo Soyuza [The program of the Communist Party of the Soviet Union]. KPSS $v$ rezolyutsiyakh i resheniyakh sezdov, konferentsiy i Plenumov CK [CPSU in resolutions and decisions of congresses, conferences and plenums of the Central Committee]. Moscow, Politizdat Publ., 1986. Vol. 10, pp. 81-185.

12. Mayakovskiy V. Rasskaz Khrenova o Kuznetskstroe $i$ o lyudyakh Kuznetska [Khrenov's story about Kuznetskstroy and the people of Kuznetsk]. Available at: https://www.culture.ru/poems/21289/rasskazkhrenova-o-kuzneckstroe-i-o-lyudyakh-kuznecka (accessed 1 October 2021).

13. Berdyaev N.A. Sotsializm kak religiya [Socialism as a religion]. Voprosy filosofii $i$ psikhologii, 1906, book V (85), pp. 508-545.

14. Bulgakov S.N. Khristianstvo i sotsializm [Christianity and socialism]. Geroizm i podvizhnichestvo. Moscow, Russkaya kniga Publ., 1992. pp. 210-253.

15. Zheltikova I.V. Kogda nastupaet budushchee? Obrazy buduschego Rossii vtoroy poloviny 20 veka [When does the future come? Images of the future of Russia in the second half of the 20th century]. Mezhdunarodny zhurnal gumanitarnykh i estestvennykh nauk, 2018, no. 8, pp. 99-106.

16. Kolontay A. Skoro (cherez 48 let) [Coming soon (after 48 years)]. Available at: http://www.fedydiary.ru/aleksandra-kollontaj-rasskazy-povest-lyubov-trekh-pokolenij/ (accessed 1 October 2021).

17. Gurova O. Ot bytovogo asketizma k kultu veshchey: ideologiya potrebleniya v sovetskom obshchestve [From everyday asceticism to the cult of things: the ideology of consumption in Soviet society]. Lyudi $i$ veshchi v sovetskoy i postsovetskoy kulture. Novosibirsk, Novosibirsk State University Publ., 2005. pp. 6-21.

18. Communism and consumerism: the Soviet alternative to the affluent society. Eds. T. Vihavainen, E. Bogdanova. Leiden, Brill, 2015. 172 p.

19. Sinitsyn F.L. Formirovanie «obshchestva potrebleniya» v SSSR: ideologicheskiy vyzov dlya vlasti (19641982 gg.) [Formation of a «consumer society» in the USSR: an ideological challenge for the authorities (1964-1982)]. Vestnik VolGU. Seriya 4. Istoriya. Regionovedenie. Mezhdunarodnye otnosheniya, 2021, vol. 26, no. 3, pp. 84-94.

20. Rossiyskiy gosudarstvenny arkhiv literatury i iskusstva (RGALI) [Russian State Archives of Literature and Art (RSALA)]. F. 2924, Op. 2, D. 1319.

21. Grushin B.A. Chetyre zhizni Rossii v zerkale oprosov obshchestvennogo mneniya: ocherki massovogo soznaniya rossiyan vremen Khrushcheva, Brezhneva, Gorbacheva i Yeltsina [Four Russian lives in the mirror of public opinion polls: essays on the mass consciousness of Russians in the times of Khrushchev, Brezhnev, Gorbachev and Yeltsin]. Moscow, Progress-Traditsiya Publ., 2001. 624 p.

22. Pyzhikov A.V. Khrushchevskaya «ottepel» [Khrushchev's «thaw»]. Moscow, Olma-Press Publ., 2002. 509 p. 
23. Aksyutin Yu.V. Khrushchevskaya «ottepel» $i$ obshchestvennye nastroyeniya v SSSR v 1953-1964 gg. [Khrushchev's «thaw» and public sentiment in the USSR in 1953-1964]. Moscow, ROSSPEN Publ., 2004. $486 \mathrm{p}$.

24. Fokin A.A. «Kommunizm ne zagorami»: obrazy budushchego u vlasti i naseleniya SSSR na rubezhe 1950-1960-kh godov [ "Communism is not far off»: images of the future in power and the population of the USSR at the turn of the 1950s-1960s]. Moscow, Politicheskaya entsiklopediya Publ., 2017. 221 p.

25. Verdery K. What was socialism, and what comes next? Princeton, NJ, Princeton University Press, 1996. $312 \mathrm{p}$.

26. Chernyshova N. Soviet consumer culture in the Brezhnev Era. London, New York, Routledge, 2013. 280 p.

27. Inglehart R., Foa R., Peterson R., Welzel C. Development, freedom and rising happiness: a global perspective (1981-2007). Perspectives on Psychological Science, 2008, vol. 3, no. 4, pp. 277-278.

28. Bogacheva N.V., Sivak E.V. Mify o «pokolenii Z» [Myths about «Generation Z»]. Moscow, SRU VShE Publ., 2019. 64 p.

Received: 8 October 2021. 